\title{
JAVANESE CULTURAL WORDS IN LOCAL NEWSPAPERS IN CENTRAL JAVA AS A LANGUAGE MAINTENANCE MODEL
}

\author{
Deli Nirmala*
}

\begin{abstract}
ABSTRAK
Unsur kultural bahasa Jawa yang berupa kata atau ungkapan merupakan unsur linguistik yang sangat khusus yang hanya dimiliki oleh bahasa maupun masyarakat Jawa. Artikel ini bertujuan untuk menggambarkan unsur kultural Jawa seperti apakah yang dapat ditemukan dalam surat kabar harian di Jawa Tengah, apa yang direpresentasikan oleh unsur kata kultural Jawa itu, dan mengapa unsur itu digunakan dalam surat kabar harian di Jawa Tengah. Pengumpulan data dilakukan dengan metode non-participant observation, yang dilanjutkan dengan page-filing and note-taking techniques. Metode referensial, reflective-introspective, dan abductive inferential digunakan untuk menganalisis data. Hasil analisis menunjukkan bahwa unsur kata kultural Jawa yang ditemukan dalam surat kabar lokal di Jawa Tengah merepresentasikan festival, ritual, pandangan / nilai budaya Jawa, kegiatan sosial, perasaan, pikiran, tingkah laku dan pengalaman lainnya. Unsur kata itu menjadi indikator bahwa para jurnalis surat kabar lokal di Jawa Tengah memiliki sikap yang positif terhadap bahasa Jawa. Hal ini menjadi model pemertahanan bahasa Jawa di media massa. Ini mengimplikasikan bahwa unsur-unsur itu telah tersimpan dalam memori jangka panjang yang terekam dalam manah yang digunakan bila dibutuhkan untuk komunikasi. Keberadaan konsep dalam manah menjadikan pemertahanan bahasa Jawa mungkin terjadi yang didukung oleh sikap positif terhadap bahasa Jawa.
\end{abstract}

Kata Kunci: unsur kata kultural Jawa, pemertahanan bahasa, khusus, surat kabar lokal Jawa Tengah

\begin{abstract}
Javanese cultural words are the linguistic units which are very specific to Javanese culture and society. This article aims at describing what Javanese cultural words that are found in the local newspapers, what they represent, and why they are used in the local newspapers in Central Java. Non-participant observation is used to present the data for analysis, continued with page-filing and note-taking techniques. Referential, reflective-introspective, and abductive inferential methods are used to analyze the data. The result indicates that the Javanese cultural words found in the local newspapers represent festivals, rituals, Javanese ways of life, social activities, actions, feelings, thoughts, behavior, and experiences. The words become the indicators that the journalists of the local newspapers in Cental Java have positive attitudes toward Javanese words. This becomes a model for language maintenance of Javanese. This implies that the words are stored in the long-term memory, that become mental image, which are used when needed by the user for communication. The existence of the concepts residing in the mind will make the Javanese language maintenance possible, which is supported by the attitudes of the Javanese.
\end{abstract}

Keywords: Javanese cultural words, language maintenance, specific, newspapers in Central Java

\footnotetext{
* Faculty of Humanities Diponegoro University Semarang, Indonesia.
} 


\section{INTRODUCTION}

Words like nyadran (a kind of ritual before fasting month, Ramadhan), nyekar (visiting graveyard by spreading roses or yasmine on the cemetary), malem selikuran (feast in the twenty-first day of the fasting month, Ramadhan), dugderan (a festival before the fasting month) - in Javanese it is pronounced dhugdheran-- can be found in local newspapers in Central Java written in bahasa Indonesia. The words used in the local newspapers are placed as a part of the titles of the rubric or the article, which are sometimes mixed with bahasa Indonesa expressions. They can be categorized as Javanese cultural words since they are specifically found in Javanese society. If you are Javanese, you will find the words in your daily life. Since they are used for referring to events happening in the society, the question is why those words are used in local newspapers in Central Java written in bahasa Indonesia.

The question inspires me to write this paper. Therefore, the Javanese words which are culturally bound used in the local newspapers in Central Java are going to be elaborated. Besides, the existence of the Javanese cultural words in local newspapers can be a model of Javanese language maintenance. Accordingly, the maintenance reflected by the use of the cultural words will be elaborated too. In other words, this paper will explain what cultural words represent and how and why they are used in the local newspapers in Central Java.

Talking about cultural words is not a new topic. Wierzbicka (1991:333) studied Japanese cultural key words and their connection with Japanese core cultural values. She proposed how to understand cultures through their key words. Compared to what Wierzbicka (1991) studied, this paper has a different object i.e. Javanese cultural words found in the local newspaper in Central Java. Besides, this paper tries to show the connection between Javanese cultural words found in the local newspaper as a model for Javanese language maintenance.

Another study done by Goddard and Wierzbicka (2004:153) discusses cultural scripts as a technique for describing more detailed topics in ethnopragmatics. They do not only study cultural words but also speech acts. Using semantic primes (Goddard in Goddard and Wierzbicka, 2004:155),
Goddard and Wierzbicka (2004:155) can show that there may be a universality in languages. According to Goddard and Wierzbicka (2004:157), cultural scripts are used to show what underlies norms, what the social members should do and feel in thought, action, feeling, and speech in a certain cultural situation. If we look at what Goddard and Wierzbicka (2004) studied, we can say that this paper has different focus and aspect of study.

In relation with Javanese cultural words, there is a study done by Siti Mukminatun, Rahmi D. Andriyani, and Erna Andriyani (no year) talking about Javanese addressing terms and kindship system used in Yogyakarta Royal Palace. This study has a different object of the study from that of this study. Besides, this paper shows the use of Javanese cultural words as a model for maintaining Javanese language.

Wierzbicka (1997:2) mentions that the keywords here mean the prominent words in the culture among other things the word referring to food that can be the basis for understanding the culture. In this paper, I am interested in discussing what cultural words are prominent in the local newspapers in Central Java and what they represent. Besides, what makes the journalists use those words are in the local newspapers in Central Java.

The theories used to answer the questions above are cognitive linguistic theory, embodiment theory, blending theory, and mapping theory. The cognitive linguistic theory used is the theory proposed by Geeraets and Cuyckens (2007) and Evans and Green (2006). Geeraets and Cuyckens (2007:5) said "Language ... is seen as a repository of world knowledge, a structured collection of meaningful categories that help us deal with new experiences and store information about old ones". This means that language can reflect what people experience stored in the mind and relate it to their new experience. Furthermore, Geeraets and Cuyckens (2007:5) said "... language is a way of organizing knowledge that reflects the needs, interests, and experiences of individuals and cultures". To support this, they also said “... human reason is determined by our organic embodiment and by our individual and collective experiences". This shows that meaning is constructed not only based on individual experience but also collective 
one. In constructing meaning, according to Evans and Green (2006) people connect their mental spaces back to that constructed earlier in the ongoing process of language production in interaction with other people. Furthermore, Evans and Green (2006:363) said that in constructing meaning there is a dynamic process called conceptualization. In this process, meaning arising is constructed based on what resides in the mind before and what is experiencing. Therefore, some words have more than one level of meaning like what Kittay (1987) said supported by Nirmala (2012).

From the explanation above, it can be assumed that language pertains what human as an individual or a group member experiences in life. In order to maintain her/his life, human has to interact with others to fulfill her/his needs, express her/ his feeling and thought. The experience human has is embodied, meaning that human experiences bodily or visually or sensically. This is supported by Nirmala (2012:176-190). The knowledge of experiencing is stored in the mind in the form of conceptual structures. They are used in language production for interaction. Therefore language reflects what is in the mind. When $\mathrm{s} /$ he produces language $\mathrm{s} / \mathrm{he}$ deals with meaning.

Meaning, in this case, is constructed. Meaning is constructed through conceptualization of old knowledge to new knowledge reflected in new words. When the word memampukan (Kompas, 16 November 2014 , p. 21) said by Sudaryanto, for example, is a new word. It is derived from the old word mampu (capable). Before the word memampukan (enable) is used, the word mampu was created. By using old knowledge conveyed in the word mampu the speaker tries to add new knowledge reflected in the word memampukan. What Geeraets and Cuyckens (2007:5) said is supported by the embodiment theory proposed by Lakoff and Johnson (1999:20) saying "An embodied concept is a neural structure that is actually part of, or makes use of, the sensorimotor system of our brains. Much of conceptual inference is, therefore, sensorimotor inference". This can make our cognitive capacity have different mappings reflected in the language.

Related to mapping theory, Fauconnier (1997:2) said “... mappings between domains are at the heart of the unique human cognitive faculty of producing, transferring, and processing meaning". Furthermore, he said that the idea contains two different strong views namely general procedures and principles for meaning and reasoning which consists of conceptual projection, conceptual integration and blending, analogy, reference, and counterfactual. Besides, the idea has views on the organization of cognitive domains which cannot be directly accessed. Fauconnier (1997:149-150) mentions that there are four principles of blends namely cross-space mapping, generic space, blend, and emergent structure. These principles may indicate how new words are conceptualized in the mind. For example, in blending principle, a new word is created by using an old word representing old knowledge, which is blended with new knowledge representing new word. Besides, mental lexicon helps find a suitable lexical item.

Lakoff and Johnson (1999:19) say that language reflects what human experience in their life. When humans have different experiences humans have different words for representing their experiences. In relation with cultural words, both mapping and blending theories can be used to explain how cultural words are very specific that can make languages different from one to another. According to mapping theory, words stored in the mind are those based on human experience. When people live in different geographies, for example, they have different experiences of what they eat, what they feel, what they hear, and what they think. For example, Javanese eat rice, casava, corn, while Ambonese eat $s a g u$. This may cause the way they eat, the way they cook different from one culture to another culture.

In relation with language maintenance model, human seems to have mechanism to conserve or protect her/his language. Human may have a model which is automatically applicable for the community members. From the studies observed, family domain is the most influencial. Like what Purwoko (2011:26) supports, Crystal (2000:19) said that language maintenance is not only a matter of linguistic but also non-linguistic factors, among other things human attitude towards her/ his language in transferring language to her/his younger generation. Purwoko (2011:26) said that language maintenance is not only a linguistic matter but also the realization in protecting their 
social and cultural identity. As stated by Krauss in Crystal (2000:20) in connection with the level of language endangerment, when a language is not learned anymore as the first language, it can be considered as dying. This can be inferred that the language life is dependent on the attitude of the parents or caretakers in transmitting their language competence to their children. In other words, if the parents or caretakers do not want to transmit their language to their children, their language may be in endangered situation.

Family has an important role in maintaining language. This is due to the fact that family members can form the children's language competence. As Krashen (1982:10) said that a child will acquire a language while an adult will only learn it. If we look at how a baby acquires a language, we can understand this that family has a very strong role in making the family members know the language they are exposed to. Therefore, Javanese family members will be competent in Javanese if they support their children's acquisition of Javanese. The exposure can be through their conversation among the family members to the children, story telling of the caretakers to the children, or other media.

In the local newspapers in Central Java, Javanese words are used or mixed with bahasa Indonesia expressions. The words can be grouped as those referring to festivals, rituals, Javanese ways of life, social activities, actions, feelings, thoughts, and experiences. The question is why the Javanese words are used in the local newspapers in Central Java, which are written in bahasa Indonesia. This may be caused by the existence of old knowledge stored in the long term memory which is already embodied then stored in the long term memory. Besides, there are certain attitudes towards Javanese in relation with maintaining Javanese cultural identity. This will be discussed in the following subtopics.

In relation with attitude, psychologist Irving Sarnoff (1960) in Liang (2015:38) discusses attitude as "a disposition to react favourably or unfavourably to a class of objects"; then Liang (2015:38) added that attitude can be investigated through inference of how an individual responds towards a certain object. Furthermore, Liang (2015:39) mentions that there is a cognitive model of language attitudes comprising affective, behavioral, and cognitive. This division taken from Cargile et al. (1994), Riagáin (1997), Baker (1992), Ladegaard (2000) in Liang (2015:39), which is also called the ABC model, which views language attitudes as being comprised of affective, cognitive, and behavioural aspects. The cognitive aspect indicates what people believe about a certain object, for instance, the accuracy of different language variations. The affective aspect indicates how people view on a certain object, e.g, whether people agree or disagree with someone's style. The behavioural aspect indicates that people tend to do something in a certain way. Fabricius (2005) investigated language attitudes towards standard and regional accents using quantitative and qualitative analysis. Referring to the types of attitudes proposed by Cargile et al. (1994), Riagáin (1997), Baker (1992), Ladegaard (2000) in Liang (2015:39), the research conducted by Fabricus (2005) can be categorized as affective aspect of attitudes.

There are some subtopics to discuss. The first is the Javanese cultural words found in the local newspapers in Central Java. The second is related to what those words represent. The third is how the existence of the cultural words can be a model for maintaining Javanese cultural identity.

\section{RESEARCH METHODS}

There are some methods used in this research for presenting and analysing data. Non-participant observation (Sudaryanto, 1993) and page filing (Crowley, 2007) are used to collect the data. The data are the Javanese elements in the local newspapers consisting of Jawa Pos Jateng, Jawa Pos Radar Semarang, Jawa Pos Radar Kudus, Jawa Pos Radar Banyumas, Suara Merdeka, Wawasan, Solo Pos, and Tribun Jawa Tengah. The Javanese expressions are classified according to the referents whether they belong to festival, ritual for example as Javanese cultural words. To determine whether they are cultural depends on whether they are prominent. Reflective introspective method (Sudaryanto, 1993) is used for determining whether they are cultural or not. From the classification, it can be seen how the Javanese expressions represent. From the analysis, it can be seen that the use of Javanese expressions in the local 
newspapers can be a language maintenance model. Some methods namely referential and reflective introspective methods by Sudaryanto (1993), abductive inference technique (Krippendorff, 2004) are used to analyze the data. The referential method is used to show the referents of the Javanese expressions used in the local newspapers in order to show their representations, while abductive inferentical technique is used to give a picture of how Javanese is maintained in the local newspapers in Central Java.

\section{Findings and Discussion}

The following are the elaboration of the referent and representation of Javanese cultural words found in the local newspapers in Central Java, the Javanese language maintenance model as the implication, and the journalists' attitude, inferred, towards Javanese.

\section{Javanese Cultural Words}

Javanese cultural words identified in the local newspapers can be grouped as festivals, rituals, Javanese ways of life, social activities, actions, feelings, thoughts, behavior, and experiences. They can be considered as cultural words since they are prominent in the life of the Javanese society in Central Java. Wierzbicka (1997:1) said that words are closely related with the societies using them. For example, the words in food can be seen that they are different in any languages. This makes them not easily translated into another language (Wierzbicka, 1997:1). The words presented in this paper deal with the words which can be said as specific to Javanese. For example, the word dhugdheran (Semarang festival welcoming Ramadhan - the fasting month. This tradition does not exist in another culture. A similar event may exist but the word used to refer to is different. Wierzbicka (1997) mentions that different words used for the same referent due to different experiences the society has. The experience may be visual, bodily, emotional, etc. As Wierzbicka (1997:5) “...words with special, culture-specific meanings reflect and pass on not only ways of living characteristics of a given society but also ways of thinking".

\section{Referent and Representation of Javanese Cultural Words}

Words or expressions are used for categorizing the world. They are used for referring to the entity meant by the speaker. When communicating with other people, they use the words that both speakers interacting each other have the same agreement about the words used to refer to a certain entity. By having the same agreement, they have mutual understanding of the langueage they use. This indicates that people from different languages will have different agreement or convention about the words used. Therefore, different languages have different words or expressions to refer to similar entity or concept.

Different languages may convey different backgrounds namely geography, social class, field of study, profession, and culture. The differences result in different experiences they have. This causes their lexical items different from one another. This is due to the fact that they have different mental lexicon stored in the mind. From cognitive linguist's point of view especially in embodiment theory as stated by Lakoff and Johnson (1999), language is believed as the experience embodied maybe visually, physically, psychologically, etc. The embodied experience can be identified from the words used. For example, the expression in Indonesian semangatnya membara (His spirit is flaming) can be identified that the word membara may be based on their embodied visual experience when looking at a flame. Now the question is why the Javanese words referring to festivals, rituals, Javanese ways of life, social activities, actions, feelings, thoughts, behavior, and experiences are used in the local newspapers in Central Java written in bahasa Indonesia.

Local newspapers present all the events or happenings in the society. They can be a picture of what really happens in the society. Therefore, when this research was conducted in the months where special events happened namely fasting month, Ramadhan, followed by Lebaran day, the words used in the local newspapers are those referring to the festival, ritual, socio-economic activity, and philosophy of life which are connected to the events. Therefore, the Javanese expressions that can be categorized as Javanese cultural words that are found in the local newspapers in Central 
Java refer to festivals, rituals, Javanese ways of life, social activities, actions, feelings, thoughts, behavior, and experiences.

The cultural word which conveys festival is the word (1) dugderan. Dugderan prounced in Javanese as dhugdheran is a festival which is usually performed to welcome Ramadhan -the fasting month for moslems. The event is usually carried out during one week prior to the fasting month. It is organized by the mayor of Semarang including the staff to take part in the carnival wearing Semarang traditional costumes. The ceremony is conducted in Masjid Agung Jawa Tengah. The word Dhugdheran is only found in Semarang. As what Wierzbicka mentions, the word Dhugdheran is a cultural word of Semarang region.

The next is the word representing ritual namely (2) Malam Selikuran -"Kebon Raja Sudah Tak Ada, Malem Selikuran Dikembalikan". Malem selikuran is a kind of ritual done in the twentieth day of Ramadhan month. The expression indicates the day when the moslems have had breakfast for 20 days. The ritual is called selamatan that is a kind of ceremonial meal awarded to the mousque visitors. Before enjoying the meals, they pray first led by kyai -the person who leads the prayer. In the event, the most important thing is the praying. The meal is the consquence for the people who have sacrificed a part of their rizki -what God gives. It is called sedekah-a part of what God gives given to people surrounding or the poor.

Another example of the word representing ritual is (3) Yuli Sekeluarga tiada saat Hendak Nyekar Ibunda (SM, Sabtu Wage, 19 July 2014, p. 1). Nyekar is a kind of tradition that is done by visiting graveyard by spreading roses or other flowers over the cemetary. Nyekar is done by some people when they want to have a special event. Some people visit graveyards before the fasting month or Ramadhan and before Lebaran. There are special days when nyekar is done. For example, the day before the wedding, before the fasting month or at the end of fasting month or before Lebaran. In other words, it is done when someone will have a special event in their life or family, for example, when they are going to carry out a wedding. The purpose is to pray for the late, for example the late parents or grandparents or great grandparents or great great grandparents or relatives or the people honored.

The expression referring to social activity can be exemplified by the expression (4) $e e$ ...Jamune (Profil Orang Sukses) (SM: Fokus Jateng: Sukoharjo, Kamis, 10 July 2014, p. 27). The expression e e ...Jamune is usually used for calling jати (herbal medicine) seller who passes by when someone wants to buy jamu. This shows that in the society there is a profession called jamu seller. Being jamu seller, someone can earn money for a living. This can also be an economic activity. In Central Java, jamu is very popular. Now, jamu is not only home industry but mass industry. For example, Jamu Jago, Jamu Nyonya Meneer, Jamu Air Mancur, Jamu Sidomuncul produce and trade jamu not only for domestic consumers but also foreign consumers. Their product is packaged like chemical medicine, namely capsule. Even though industrial jатu is very popular, traditional jamu still exists not only in Central Java but also in Jakarta or other cities in Indonesia.

Another example of the expression referring to social activity is (5) Ngisor Asem. RS St Elizabeth Pernah jadi Kantor Militer Jepang. Kawasan Perbukitan Candi Baru (SM: Semarang Metro, Kamis, 7 August 2014, p. 21). Ngisor asem is a Javanese expression meaning 'under tamarin tree'. The word ngisor means 'under', while the word asem means 'tamarin' in this case a tree. The word asem may refer to either the fruit or the tree. In the past, asem is very popular since it is planted in both sides of the street. Sometimes it is planted in the housing area. The trees can be a shade from rain or heat. So peple love to be under the tamarin tree for taking shelter. A small economic business is sometimes done under the tree. For example, a business or service like a male hairdresser. The service can also be an economic activity. In addition, ngisor asem is a place for gathering, talking each other for gossipping. It can be for a meeting pot for people who pass by.

The next example of social activity is (6) Masjid Ki Ageng Pandanaran Setiap Lebaran jadi Jujugan Peziarah (SM: Semarang Metro: 
Kamis 24 July 2014, p. 1). The word jujugan means 'destination'. When the word is combined with peziarah (someone who visits graveyard), it indicates a social activity that is visiting graveyard as a kind of social activity. This word indicates that the place which becomes the destination is very popular, meaning that many people go there. For example, when someone says Semarang dadi jujugan wong manca negara mean that Semarang is a popular place for foreign people. This shows that there are many tourists visiting Semarang. If many tourists visiting the place, it becomes a source of social economic activity of Semarang authority and the community.

Social activity is also represented by ngopi in (7) Ngopi dalam "Belajar dari Secangkir Kopi" (SM: Her Spirit, Minggu, 20 July 2014, p. 17). Ngopi refers to drinking coffee, which is usually done at home or warung or food stall. While ngopi usually people spend much time sitting and talking or gossipping. It is usually done in the evening until late at night. The food stall is sometimes as a meeting pot for gathering without certain agenda. People coming are not invited, they are voluntarily meeting people in the food stall, they are passers by or people living close to the food stall. Even, they live in a little farther from the food stall. Now, ngopi in warung is not as popular as in the past especially in urban areas. Maybe people drink coffee but not for spending much time sitting and talking or gossipping. They may drink coffee at bar. In this case, the word ngopi is specific to Javanese since there is no suitable word in another language even Indonesian that can replace it.

An example referring to Javanese life value is the expression sangkan paran in (8) Mudik Menghayati Soal Sangkan Paran (SM: Minggu Kliwon, 30 July 2014, p. 1). Sangkan paran meaning where we come from, is a philosophy of life teaching about how Javanese people realize where they come from. They realize that they are created by God and they will return to God (Sofwan, 1999:68). The expression sangkan paran in the sample Mudik Menghayati Soal Sangkan Paran can be considered as an adopted value from Javanese Life Value. From the sample, I can infer that the value is enlarged by the journalist to include Javanese value in Islamic day situation. Lebaran day is the celebration of the breakfast after one-month fasting. To clean the soul, people have to apologize each other. This life value motivates Javanese people to always respect their parents, since they take care of them, educate them, and make them grow and develop. Therefore, when Lebaran comes, they have strong motivation to go home in order to meet their parents, even meeting their parents is not done only during Lebaran Day, but also all the days of the years. However, Lebaran Day involves a ritual which is executed not only for their parents but also relatives or people living in their parents' neighborhood.

Another example of Javanese life value is (9) Rikuh pakewuh dalam artikel "Makna Kejernihan Bahasa Politik" (SM: Wacana, Kamis, 10 July 2014 , p. 6). The expression rikuh pakewuh is an expression that refers to feeling in behaving especially for bad deeds or something shameful. This is a feeling that requires much consideration in behaving. Someone has to have this feeling rikuh pakewuh when s/he does something which is connected with other people or maybe threatened other people. However, when something is true, s/ he should not have the feeling rikuh pakewuh. The expression rikuh pakewuh can not be translated even into bahasa Indonesia. Therefore, it is considered specific to Javanese.

The following is an example of the expression used in social setting when people interact each other and there is something unexpected happened. To ask what happened, Javanese people say (10) Piye jal?. The question piye jal? is usually uttered by someone when s/he wants to ask others' reaction or response or opinion about something that unexpectedly happens. This expression is used in the local newspapers in Central Java being the title of the rubric dealing with what happens in the society or surrounding or public facility. This rubric is used to encourage audience to publish what they see, experience and ask the authority responsible for the case or problem.

Another example used to interact with other people is Javanese particle kok like in example (11). (11) Kok dalam "Petani Sulit dapat Pupuk" (SMS dari masyarakat) (SM: Semarang Metro, Sabtu, 19 Juli 2014, p 29). The word kok is used to indicate to ask the reason why something happens. For example, kok ngono ta? (why does it happen like that?). Another example, kok adoh 
tenan omahmu? (why is your house too far?). The expression is used also to ask something that is beyond what is expected. The word kok in the sample is used to ask why the farmers can not get the fertilizer to make their rice field fertilized in order to get good crop.

The word referring to an event can be seen in the example (12) Yang Seru dari KangenKangenan (SM: Minggu, 3 August 2014, p. 19). The word kangen-kangenan is a Javanese word to indicate a situation in a reunion of people who have not met each other for a very long time. During Lebaran Day, when people visit their hometown to meet their parents and relative living in different cities or areas with the places where they live, they usually gather to have a reunion that can make them gather. They are school mates at elementary or secondary levels. When they meet together they express their longingness in the meeting by asking and sharing what they have done so far. Talking about career, family, and their memory about the time they were schooling is the most favorite agenda in the kangen-kangenan event.

The next is (13) Kupat Lepet: Kupat Lepet Janur Tuwo menawi Lepat Nyuwun Ngapuro $(\mathrm{sic})^{1)}$. The expression Kupat Lepet: Kupat Lepet Janur Tuwo (sic) menawi Lepat Nyuwun Ngapuro (sic) is used to express apology in Lebaran Day. In Javanese, this expression is called parikan. It is a kind of poem having two lines; the first line has a rhyme, the second line resembles the first line in rhyme but it does not connect each other in meaning. Kupat or ketupat in bahasa Indonesia means rice cakes boiled in plaited young coconut leaves (from The Jakarta Post, Friday, November 14, 2008). Lepet is a kind of snack made from glutinous rice boiled in a tube-like plaited young coconut leaves. Janur is young coconut leave, and tuwa means old. Menawi means if; lepat means wrong; nyuwun means ask and ngapura means apology. This expression is used in local newspapers in Central Java as a rubric which includes apologic expressions coming from individuals or institutions.

Another example of Javanese cultural words is (14) Balane Enyong. The expression balane enyong is Tegal Javanese dialect meaning 'my group member' or 'you belong to my group'. This is used to be the title of the rubric. The rubric entitled Balane Enyong is to show the public participants in the development of Tegal. The articles in this rubric shows the progress or the interaction between the government or the authority and the society in dealing with the development of the region. It can be inferred that the expression indicates the closeness or in-group strategy to encourage the society to always involve in the governmental activities especially the one which can develop the region that is Tegal. The authority places the society in the same group or strata. This may be used to attract the society to take part in governmental activity.

Another rubric entitled (15) Ngresula is used to express the community's feeling regarding to the policy concerning the tariff of social problems. The word ngresula means 'complain'. In the rubric Ngresula: Kartun Mohlaah...Kawin Larang...!!!! Pan Nunggu sing gratis baee ${ }^{2)}$...!!! (Radar Tegal: Jurnal Guru, Selasa 15 July 2014, p. 2), I can see how the journalists give space to common people to express their complaint about anything they found in connection with the government policy. In the rubric, the readers of the newspapers sent their complaint directed to the government, complaining the tariff of marriage which is very expensive. By saying Kartun Mohlah (I do not want to) ... Kawin Larang (marriage tariff is expensive) ...!!!! Pan (later) Nunggu (wait for) sing gratis baee ...!!! (which is free).

Not only for expressing the above matters discussed in the previous samples, Javanese cultural words found in the data are those related to bahavior; how Javanese behaves in the society. See the following example.

The following words found are those which can be categorized as the words representing behavior of Javanese people. These expressions are used by a person interviewed by the journalist. (16)

1) The words ngapuro, neko-neko, boso, must be written ngapura, basa, neka-neka. This /a/ is pronounced as [a]. (see Utomo, 2009)

2) The word baee pronounce [baee] is equal to wae, but there is a sound lengthened. The word characterizes Javanese Tegal Dialect. Since the newspaper from which the word is found is directed to Javanese Tegal people, it can be inferred that the word bae may be adjusted to Tegal dialect. 
Pesan Guru: Jadi Panutan, berharap Amanah. Kesederhanaan Jokowi ...pribadi Jokowi sangat sederhana, tidak neko-neko (sic). Dia itu tidak aeng-aeng ... "Dia tidak hanya ngajeni pada gurunya .... Dia nggak pernah pakai bahasa ngoko, mesti boso ${ }^{3}$. Dia itu nguwongake uwong. The words panutan, neka-neka, aeng-aeng, ngajeni, mesti basa, and nguwongake uwong can be characterized as Javanese cultural words conveying behavior. The word panutan means moral model. Someone who becomes panutan means that $\mathrm{s} / \mathrm{he}$ has good moral in her/his life. S/ he can be a model of others. S/he has good deeds in her/his life that $\mathrm{s} /$ he becomes panutan. The word neka-neka means various in negative sense or doing something unexpected. It is difficult to find the meaning in another language even bahasa Indonesia. If someone says dheweke ora neka$n e k a, \mathrm{~s} /$ he means that someone referred acts as common people nothing done unexpectedly. S/he is in a normal corridor of moral or habit. However, if $\mathrm{s} / \mathrm{he}$ is neka-neka, $\mathrm{s} /$ he breaks the rules or laws or ethics. The word aeng-aeng is similar to neka-neka. However, the word ngajeni refers to a respecting behavior. S/he respects others whether they are young or old. The expression mesti basa refers to a respecting behavior. In Javanese, when someone speaks with an older person or a respectful person or an honored person, s/he uses Javanese speech level directed to them that is basa indicating deference or social asymmetry or hierarchy. The word nguwongake means respecting others.

The words or expressions explained above are behavioral words in Javanese. The words convey good moral teching in behaving in the society from the smallest one that is family to the biggest one that is the public. These indicate that Javanese has a good behavior teaching among other things someone has to respect others, have good deeds, does not do anything that is disliked or not expected by individual or the society.

The following word in (17) digadang-gadang $(\mathrm{sic})^{3)}$ in Tajuk Rencana "Memilih Pemimpin pada Bulan Suci (SM: Wacana, Rabu, 9 July 2014, p. 4) is the word to show a hope. The word digadhanggadhang meaning 'it is hoped and expected' in the

3) The word digadang-gadang should be written digadhang-gadhang (see Utomo, 2009). data is used to show the social hope concerning the regional election for the regent or mayor. This word expresses the hope of the society about the suitable leader for the regency. The word is not easily translated in bahasa Indonesia or English. In bahasa Indonesia, the word can be translated into diharapkan, but semantically the word digadhang-gadhang has stronger sense than the word diharapkan. The word digadhang-gadhang includes the meaning of expectation or something idealized, and the expectation in digadhanggadhang is much stronger than that in diharapkan. The words or expressions discussed above are considered culturally specific to Javanese, since they do not have Indonesian or other language equivalences. The specific words belong to those which publicly involve members of the society. Since they are for example, the words dhugdheran, ngopi. The words refer to an activity done publicly at a certain location or time. For example, dhugdheran is performed when the fasting month will begin. This is organized in a certain place that is in the area of Masjid Agung of Semarang or Masjid Agung Jawa Tengah and or near Johar market. If I look at what Wierzbicka (1997:2) said, I can say that the words mentioned are specific to Javanese culture. The specificity can be found in the experience represented by the words. For example, the word dhugdheran, is derived from the word dhug (the sound of the hitting a drum) while dher (bang) - an (suffix indicating activity).

Language Attitude toward Javanese Resulting from the Use of Cultural Words

From the data observed, I can infer that there must be a purpose for using Javanese words in the local newspapers written in Bahasa Indonesia. The inference is derived from the use of the words which represent festival, rituals, for example. The question is why they keep using the words eventhough they present news in bahasa Indonesia.

This indicates that there is a strong reason to keep the words that is to make the words exist in their mental lexicon or the audience's mental lexicon. The use of the words shows the exposure of Javanese vocabulary to the audience. This can also be said that the words do not have their equivalence in bahasa Indonesia. Therefore, the 
journalists use Javanese to express their meaning. Based on the theory proposed by Cargile et al. (1994), Riagáin (1997), Baker (1992), Ladegaard (2000) in Liang (2015:39), this research can be seen as behavioral aspect of language attitude studied. The inference comes from the use of Javanese expressions in the newspapers in Central Java Province. The journalists have strong intention using the cultural words in the newspaper. Actually, they can use bahasa Indonesia by paraphrasing the cultural words, but what they do is using the words or expressions which are directly taken from Javanese as gathered from the data sourse.

Therefore, it can be observed that the use of Javanese words in the local newspapers can show a positive attitude towards Javanese. This can be inferred that it is a good prospect for Javanese.

\section{Embodied Experiences in Cultural Words}

Cultural words used in the local newspapers in Central Java indicate the experiences that can be proven by visual experience, bodily experience, or social experience. For example, the word ngopi does not only refer to an individual experience of drinking coffee but also social experience of gathering or meeting with other people talking and sharing many issues, for example social issue. In ngopi, someone is not only tasting the coffee drink or zipping the coffee drink but $\mathrm{s} /$ he feels comfortable when $\mathrm{s} /$ he is around others talking about endless topics while enjoying not only the aroma but also the taste of the coffee. For someone who adores coffee, s/he will spend her/his time in the warung or food stall.

Another example of the cultural words embodying experience in the local newspapers in Central Java is Ngisor Asem. RS St Elizabeth Pernah jadi Kantor Militer Jepang. Kawasan Perbukitan Candi Baru (SM: Semarang Metro, Kamis, 7 August 2014, p. 21). The expression ngisor asem reflects past experience where Javanese people can use ngisor asem as a place for business or social gathering. Nowadays, ngisor asem is not popular anymore. However, the intention of preserving the experience exists in the newspaper.

If we look at the expression ngisor asem, we do not have difficulty in finding the word counterpart in bahasa Indonesia. However, this expression has a very deep social experience which does not exist at present. The social activity done by the society conveyed by the expression can not be found in the society now due to the changes of the land use now. It is difficult now to find a vacant land where tamarin trees are growing. Besides, people nowadays are very busy in their job. In addition, communication and transportation era may cause people to use their gadget for making them busy, or vehicle that can transport them to a long distance place in a very short time. This can make them unable to gather or drop in or stop in the ngisor asem. The expression reflects past experience which does not exist anymore due to some changes in many aspects of life.

Cultural Words as a Language Maintenance Model Cultural words used in local newspapers in Central Java can be a model of Javanese language maintenance. Like what I found in the data, the words referring to rituals, social activities, philosophy of life, can stimulate the readers to store in the mind. They are used in the media that people can access or read. By exposing the words in the media, it can be assumed that the journalists purposefully make the words accessable. This makes the words exist in the readers' mind. Automatically, this becomes an input for language competence.

Based on the data, it can be stated that the cultural words used convey social experiences for maintaining or building social identity of the society of Central Java. For example, dhugdheran as a festival to welcome Ramadhan fasting month becomes Semarangese cultural identity. In the festival, the society involves performing traditional arts and creativity for merrymaking. This can enliven the days prior to fasting month. In the fasting month, people tend to concentrate on preparing the meals for breakfast (berbuka), then praying tarawih in the evening, and preparing meals for sahur or morning meals. Even though fasting month is a special month for moslem, it can also affect the life situation of the other groups living in Central Java or Indonesia. For example, Lebaran day is not only enjoyed by the moslems but also the other members of the society. Usually, in Lebaran day, malls or supermarkets offer big 
discounts during fasting month or approaching Lebaran day. In Lebaran, the moslems celebrate the day with special menu called ketupat or kupat served with curry or opor.

Cultural words used in the local newspapers in Central Java can be a Javanese language maintenance model. They can be accessed by the readers from different ages or regions. The words can be stored in the readers' mind and become the mental lexicon of the readers who are either Javanese or non-Javanese. I realize that the readers of the newspapers are not only Javanese. Therefore, the words are not only accessed by Javanese but also non-Javanese people who access the newspaper.

From the explanation I can say that cultural words used or preserved in the local newspapers may automatically preserve not only Javanese cultural words but also Javanese cultural identities. The identity that may be conveyed is the identity of spiritual life of Javanese people, togetherness, and sociability.

\section{CONCLUSION}

From the analysis, it can be concluded that the cultural words used in the local newspapers in Central Java are the words or expressions which refer to and embody experiences experienced in festival, tradition, ritual, behavior, for example, that become the identity of Javanese people. In addition, the words can be the indicators that the journalists of the local newspapers in Central Java have positive attitude which is behavioral to preserve Javanese cultural words. The attitude can make the maintenance of Javanese cultural words possible. This can be a model for maintaining Javanese language and culture.

\section{REFERENCES}

Crowley, Terry. (2007). Field Linguistics. A Beginner's Guide. Oxford: Oxford University Press.

Crystal, David. (2000). Language Death. Cambridge: Cambridge University Press.

Evans, Vyvyan dan Green, Melanie. (2006). Cognitive Linguistics: An Introduction. Edinburgh: Edinburgh University Press.

Fauconnier, Gilles. (1997). Mappings in Thought and Language. Cambridge: Cambridge University Press.
Fabricius, Anne H. (2005). "Investigating Speech Samples as Dialect in Discourse: Discourse Analysis, Phonetics, and Language Attitudes. Journal of Acta Linguistica Hafniensia vol. 37, issue 1, pp. 81-99. Downloded from http://gen. lib.rus.ec/scimag/index.php?s=investigating+ language+attitudes $\&$ journalid $=\& v=\& i=\& p$ $=\&$ redirect $=1$ on May 3, 2015 at 4.16 am.

Fauconnier, Gilles. (1997). Mappings in Thought and Language. Cambridge: Cambridge University Press.

Geeraerts, Dirk and Hubert Cuyckens, eds. (2007). The Oxford Handbook of Cognitive Linguistics. Oxford: Oxford University Press

Goddard, Cliff and Anna Wierzbicka. (2004). "Cultural Scripts: What are they and what are they good for?". Intercultural Pragmatics 1-2. pp 153166.

Kittay, Eva Feder. (1987). Metaphor: Its Cognitive Force and Linguistic Structure. Oxford: Clarendon Press.

Krashen, Stephen D. (1982). Principles and Practice in Second Language Acquisition. California: Pergamon Press downloaded on Sunday, October 25, 2015 at 11.35

Krippendorff, Klaus. (2004). Content Analysis:An Introduction to Its Methodology, California: Sage Publications, Inc.

Lakoff, George and Mark Johnson. (1999). Philosophy in the Flesh: The Embodied Mind and its Challenge to Western Thought, New York: Basic Books

Liang, Sihua. (2015). Language Attitudes and Identities in Multilingual China: A Linguistic Ethnography. New York: Springer. Downloaded from http://gen.lib.rus.ec/book/index.php?md5= $3 \mathrm{~d} 6 \mathrm{~b} 76 \mathrm{f3} 802 \mathrm{c} 760 \mathrm{a} 4 \mathrm{a} 41 \mathrm{e} 4 \mathrm{f3ab} 7218 \mathrm{cc}$ on May 3,2015 at 3.29 am.

Mattfolk, Leila. (2005). "Investigating Attitudes to 'Ordinary Spoken Language': Reliability and Subjective Understandings". Journal of Acta Linguistica Hafniensia vol.37, Issue: 1. pp.171191. http://gen.lib.rus.ec/scimag/index.php?s $=$ investigating + language + attitudes $\&$ journalid $=\& \mathrm{v}=\& \mathrm{i}=\& \mathrm{p}=\&$ redirect $=1$ on May 3, 2015 at 4.27 am.

Mukminatun, Siti, Rahmi D. Andayani, and Erna Andriyanti. (no year). "Javanese Cultural Shift Seen through the Use of Addressing Terms and Kinship System in the District of Yogyakarta Palace”. English Education Study Program, English Language and Literature Study Program, English Education 
Department, Faculty of Languages and Arts, Yogyakarta State University. Downloaded on Sunday,October 25, 2015 at 20.25

Purwoko, Herudjati. (2011). "If Javanese is Endangered, how we should Maintain it?". Proceedings of International Seminar in Language Maintenance and Shift, July 2, 2011. ISSN: 2088-6799. pp 22-30

Sofwan, Ridin. (1999). Menguak Seluk Beluk Aliran Kebatinan (Kepercayaan Kepada Tuhan Yang Maha Esa). Semarang: Aneka Ilmu

Sudaryanto, (1993). Metode dan Aneka Teknik Analisis Bahasa. Pengantar Penelitian Wahana Kebudayaan secara Linguistis, Yogyakarta: Duta Wacana University Press.

Suherdjoko. (2008). "Ketupat More than just a Tradition” in The Jakarta Post, Friday, November 14, 2008.
Utomo, Sutrisno Sastro. (2009). Kamus Lengkap Jawa - Indonesia. Yogyakarta: Penerbit Kanisius Wierzbicka, Anna. (1991). Japanese Cultural Key Words and Core Cultural Values. Language and Society, Vol. 20, no. 3 (Sep., 1991), pp 333-385.

(1997). Understanding Cultures through their Keywords. Oxford: Oxford University Press.

Williams, Ann. (2005). Investigating Language Attitudes: Social Meanings of Dialect, Ethnicity and Performance. International Journal of Applied Linguistics. Vol. 15 Issue: 3, pp 411-414. Downloaded on May 3, 2015 at 4.20 am from http://gen.lib.rus.ec/scimag/index. php?s=investigating+language + attitudes \& journalid $=\& v=\& \mathrm{i}=\& \mathrm{p}=\&$ redirect $=1$ 